\title{
A review of trade liberalisation and trade between Jordan and the United States
}

\author{
Imad El-Anis \\ The School of Social Sciences, Nottingham Trent University, Nottingham, UK.
}

Accepted 14 August, 2013

\begin{abstract}
Promoting trade is a key aspect of Jordan's development policy. As a developing country, increasing exports and maintaining a healthy balance of trade with its trading partners are amongst the government's most important goals. The Free Trade Agreement (FTA) signed with the United States in 2000 is a cornerstone of Jordan's foreign economic policy and a key test case for its broader policy of trade liberalisation. Yet while there is some evidence for a positive relationship between trade liberalisation, and increased bilateral trade and economic growth, this approach to development is also criticised for opening up developing markets to competition from their more advanced counterparts. This investigation argues that FTAs do facilitate bilateral trade but that states with large and advanced economies benefit more than small developing states and markets. To explore this argument, this study examines overall levels of bilateral trade between Jordan and the United States before and after the JUSFTA came into effect. Linear trendline projections are used to offer a comparison between experienced levels of trade and projected potential levels of trade based on pre-JUSFTA era data. The conclusions drawn are that bilateral trade between Jordan and the United States rapidly increased after 2001 and this coincided with the implementation of the JUSFTA confirming a strong correlation between the two. Furthermore, we can observe that Jordanian exports to the United States have grown more rapidly than imports. Furthermore, Jordan has benefitted from an overall trade surplus since the implementation of the JUSFTA compared to the trade deficit experienced in the pre-JUSFTA era. However, following the complete implementation of the JUSFTA, Jordanian imports from the United States now exceed exports and the Jordanian trade deficit may continue in the coming years.
\end{abstract}

Key words: Jordan, United States, free trade, economic development, policy.

\section{INTRODUCTION}

Jordan is an underdeveloped, small country located in a rather turbulent region of the Middle East. Throughout its history Jordan has faced security challenges from its neighbours as well as problems of internal development (Salibi, 1998, pp. 197-243). Although it has been an active player in regional politics, relative to its size, Jordan's economic underdevelopment has limited its capacity to act externally and to secure its domestic interests since independence in 1946. The long-term economic problems that have undermined Jordanian development and domestic stability include a high unemployment rate which officially stands at $12 \%$ but is much more likely to be around $25 \%$ of the active labour force, a large public debt of close to $70 \%$ of GDP, high levels of poverty at around $13.3 \%$ and limited industrial sector growth (World Bank, 2012). A financial crisis in 1989 saw Jordan default on its international debt obligations following which the government turned to the International Monetary Fund (IMF) for assistance (Hamarneh, 1994). This was forth- coming but with the usual requirements for structural adjustment which the Jordanian government accepted (Maciejewski and Mansur, 
Table 1. Removal of tariffs between Jordan and the USA.

\begin{tabular}{lc}
\hline $\mathbf{2 0 0 0}$ Tariff level (\%) & Phase-out period (by 2010) \\
\hline$<5$ & 2 years \\
$5-10$ & 4 years \\
$10-20$ & 5 years \\
$>20$ & 10 years \\
\hline
\end{tabular}

1996). Throughout the 1990s Jordanian economic development remained slow and public discontent rose as a result of the overarching structural changes taking place in the economy and governmental policy (Robins, 2004, pp. 166-176). While the government had traditionally maintained a significant presence in the economy and was the key actor in economic affairs, the 1989 crisis highlighted the failure of the government's economic approach. Overall, the late 1990s saw an embedding of neoclassical/liberal economic policies that related both to domestic and foreign economic policies. Privatisation, de-regulation and the creation of a 'business-friendly' environment took place at home and trade liberalisation was pursued abroad (El-Said, 2001).

The ascension of King Abdullah II in 1999 led to the further institutionalising of these neoclassical policies and Jordan has since sought to increase economic growth through the twin pillars of attracting foreign direct investment (FDI) into the Jordanian economy and facilitating trade with key international markets through Free Trade Agreements (FTAs) (Ministry of Industry and Trade, 2013). The first, and perhaps the most politically important, FTA that Jordan signed was with the United States in late 2000. The Jordan-United States FTA (JUSFTA) fully liberalised bilateral trade between the two states in goods, services and capital (with the exception of a small number of sectors which were given special status) (JUSFTA, 2000) and was only the fourth such agreement the United States had signed (the first three being with Israel (1985), Canada (1989) and Mexico (1994 in the form of NAFTA) (Lovett et al., 2005). The JUSFTA formed the cornerstone of Jordanian trade policy and was seen as test case for the benefits of liberalising trade. The government hoped that by liberalising the regulatory framework governing trade with the United States it would see an actual increase in trade levels, primarily in exports but also in cheaper imports (WTO, 2008, pp. 11-13).

This study argues that bilateral FTAs do facilitate bilateral trade between signatory states but that where FTAs exist between advanced states and those less developed, asymmetric benefits are gained by the former. To explore this argument this study explores the correlation between the implementation of the JUSFTA and changes in Jordanian-US trade, and offers some conclusions as to how beneficial it has been for Jordan's economic development over the past 12 years.
This is done by:

1. Assessing changes in the levels of Jordanian exports to, and imports from, the US market since 1992.

2. Examining the balance of trade between the two states in this period.

3. Analysing the differences in trade levels in the pre- an post-JUSFTA periods.

This study does not seek to explain all aspects of Jordanian-US trade as being caused by the JUSFTA. Instead it seeks to posit a correlation between the implementation of the agreement and overall changes in bilateral trade. The JUSFTA does, however, represent a useful case to study to analyse as a test case for Jordan's economic reforms and policy of trade liberalisation. It is also a useful case study in the broader context of the proliferation of bilateral FTAs, in particular that large markets like the United States have signed or are pursuing with smaller, developing states across the Middle East and North Africa and elsewhere. This is because the JUSFTA is one of the oldest bilateral FTAs with this high level of disparity between the signatories and therefore offers more data and policy evidence to analyse.

\section{An overview of the JUSFTA}

The JUSFTA was the first bilateral FTA signed by the United States with an Arab country and only the second FTA signed with a state in the Middle East. It was also the first time that a bilateral FTA included provisions for labour, the environment and Intellectual Property Rights (JUSFTA, 2000). It also represents a milestone in the development of Jordanian foreign and trade policy. Since the mid-1990s Jordan has successfully pursued membership in the WTO, signed multiple bilateral and multilateral FTAs (such as the Jordan-Singapore FTA of 16 May 2004; and the Greater Arab Free Trade Area) as the government pushed for greater economic liberalisation. Negotiations for the JUSFTA were launched in 1998 with the US administration of President Bill Clinton (the JUSFTA was finalised while Clinton was still in office. The Bush Administration simply ratified it in late 2000) (Rosen, 2003, pp. 51-53).

The JUSFTA was designed to lead to the total liberalisation of trade in goods and services between the two states and required the removal of all tariffs on bilateral trade by the end of 2010. The reduction to 0 per cent tariffs was scheduled in four stages (Table 1). A list of 250 Jordanian products was granted immediate $0 \%$ tariff access to the US market - none of which were leading Jordanian exports as outlined below (USTR, 2005). Jordan already had free access to the US market in all services (including services in the financial, legal and medical sectors) at the time the JUSFTA was implemented (Jardaneh, 2003). On the other hand, the 
United States did not have free access to the Jordanian market for services. The JUSFTA called for the total liberalisation of Jordan's services market for US-based and US-affiliated corporations over a ten-year transitional period. This includes the following sectors: distribution, convention services, printing and publishing, courier services, audio-visual, education, environmental, financial, health services, tourism, recreation and transport services (Jardaneh, 2003). Annex 2.2 of the agreement states that a minimum of $35 \%$ of the value of any good that is traded between the signatories must originate in the exporting country.

The JUSFTA came into effect on 17 December, 2001 and the target of reducing tariffs in all areas except those exempt to $0 \%$ has been met (Ministry of Industry and Trade, 2006). Jordanian exports to the US market are in the following sectors: textiles and clothing, Dead Sea cosmetics, orthopaedic appliances, olive oil, chemical fertilisers, pharmaceutical products, articles of jewellery, phosphates and insecticides (US Census Bureau, 2013). Immediately following the implementation of the JUSFTA, exports of textiles and clothing began to dominate Jordanian exports to the United States and accounted for over US $\$ 900$ million of Jordan's US $\$ 1.15$ billion of exports to the United States in 2012 (US Census Bureau, 2013). This sector has benefitted the most from trade liberalisation in Jordan. Likewise, the main Jordanian imports from the US market in the JUSFTA period have remained the same as in the pre-JUSFTA period, but have witnessed rapid growth in the quantity and value of sales. The leading imports are in the following areas: vehicles, cereals (wheat, rice and corn), machinery, arms and ammunition, and aircraft with the first two sectors accounting for over US\$600 million of Jordan's imports from the United States of US $\$ 1.76$ billion in 2012 (US Census Bureau, 2013). The JUSFTA agreement includes the full liberalisation of trade in each of these sectors.

\section{LITERATURE REVIEW - DOES TRADE LIBERALISATION WORK?}

In International Political Economy (IPE) there are debates about whether FTAs actually result in increased trade and if they do, if there is a positive or negative impact on economic growth. There are no universally accepted conclusions to these questions but this study seeks to form conclusions about the relationship between the JUSFTA and Jordanian-US trade [Cassing and Salameh, 2006) for an earlier study]. In the first case scholars disagree as to whether liberalising trade through lowering barriers to trade (by creating FTAs) actually results in increased trade. Sachs and Warner (1995) argue that there is a direct correlation between the two but that there are also a number of other factors that have an impact. They find that if the regulatory framework governing trade is liberalised between two states, there will need to be a measure of market complementarity for increased trade to follow. This is a key area of consideration that needs to be investigated when considering the impact of FTAs on changes in bilateral trade levels and one that this study takes into account. At the same time Jagdish (2003) finds that FTAs directly encourage trade through the removal of 'unnatural' barriers to trade. Lawrence (2006) of The Peterson Institute for International Economics (a Washington, DC-based think tank that often advises the US government) posits clear assumptions of the positive correlation between FTAs and increased trade. On the other hand, there is evidence that suggests that FTAs represent political will/desire to encourage trade between signatories but they may not be followed by increased trade (Tovias and Al-Khouri, 2004). The conclusions presented by Lawrence and Tovias and Al-Khouri rely on an acknowledgement of the connection between policy and market structures/processes, with each often affecting the other. This study adopts this assumption and considers the JUSFTA as existing not in a political vacuum or as isolated from considerations of preJUSFTA market complementarity.

There is a body of literature that explores the relationship between trade and economic growth. Much of this modern literature has its roots in earlier classical liberal economic works that built on the analyses of Smith (2003 [1776]) and Ricardo (1996 [1817]). Frankel and Rommer (1999, p. 395), for example, conclude that increased foreign trade does lead to increased economic growth domestically. They argue that "trade appears to raise income by spurring the accumulation of physical and human capital and by increasing output for given levels of capital." Likewise, Sebastian (1993) examined the relationship between the level of economic openness in developing countries and their levels of growth and found that there was a direct positive correlation. Several years later Harrison (1996) developed this field of analysis by conducting a comparative analysis of the trade policies and growth records of a number of developing countries. She again found that higher levels of overall trade (and not just exports) directly encouraged higher levels of economic growth. These studies all have their merits and the conclusions made regarding the relationship between FTAs, trade and growth are utilised in this project.

By using a model of bilateral trade with imperfect competition Baksi and Chaudhuri $(2008,2009)$ find that by reducing tariffs and other barriers to trade, bilateral trade is facilitated and increases. Over time, they find that overall welfare and economic growth (in particular industrial activity) is promoted. In their two studies, Baksi and Chaudhuri do not, however, consider differences in growth in trade, economic development and welfare that each FTA signatory experiences. This study utilises the conclusions of Baksi and Chaudhuri's model of liberalised bilateral trade to argue that FTAs promote trade, but develops a second level of investigation to differentiate 
changes in bilateral trade by trading partner (Baksi and Chaudhuri, 2008, 2009). In a similar study, Nkuiya (2013) employs a model of trade liberalisation between potentially heterogeneous open economies to assess the impact on increased trade, growth, welfare and environmental policies. He also finds that trade liberalisation in the form of mutually reducing barriers to trade encourages bilateral trade. While Nkuiya adopts a model that presumes that tariff and other barriers to trade are identical for each trading partner in an oligopolistic trade game, this study approaches Jordanian-US trade by observing differences in the levels of protection preJUSFTA and takes into account variations in the pace of liberalisation assigned to each state in the agreement, as well as the provision for exempted goods and services as outlined above.

At the same time as arguments are presented stressing the positive impact FTAs have on promoting trade and welfare, and that there is a positive relationship between trade and economic growth, these conclusions are contested. Some scholars have long criticised the neoclassical policy prescriptions [what is termed the Washington Consensus (Williamson, 1990)] of tradedriven growth that many developing states, including Jordan, have come to adopt. Perhaps most notably Andre (1978) has argued that liberalised trade merely opens up developing economies to competition by more advanced and competitive actors from developed markets, against which their own domestic actors cannot compete. They are subsequently replaced in the domestic market by foreign actors and an overall decline in the productive capabilities of the developing economy follows. This ultimately reinforces patterns of dependency between developing and developed countries in favour of the latter (Andre (1978). Wallerstein (1979) has suggested that the world is divided up into three key zones: a rich and advanced 'core', a developing 'semiperiphery' and an undeveloped 'periphery'. The relationship between these zones is one of exploitation of the poor by the rich and is manifested in trade (Wallerstein, 1979). In terms of trade the periphery has an overall deficit with the semi-periphery and core markets while the semiperiphery has an overall trade surplus with the periphery but a deficit with the core. The implications for Jordan are significant if the following analysis of the data suggests that Jordan has benefitted from the JUSFTA through growth in exports and a trade surplus or that it has experienced a trade deficit and little impact on exports (or trade overall).

Rodriguez and Rodrik (2001) offer a coherent review of the different arguments and approaches used to examine the impact that FTAs have on trade. In their study Rodriquez and Rodrik review a number of analyses that use varying methods to assess whether states with 'lower barriers to international trade experience faster economic progress' (Rodriguez and Rodrik, 2001, p. 1). Ultimately they conclude that the problems with the methodologies employed by other scholars to assess this issue results in diverse interpretations and no widely accepted findings.

Furthermore, by reviewing previous studies they find that there is little evidence to suggest that lower tariff and non-tariff barriers to trade directly impact overall economic growth (Rodriguez and Rodrik, 2001, p. 39). Rodriquez and Rodrik do offer some very interesting and useful insights into the ways in which methodologies vary and how, subsequently, there is much contestation regarding the relationship between open trade policies and economic growth. However, their work is not exhaustive in its review of previously conducted studies and ultimately assumes that liberalising trade impacts overall economic growth without first considering an intermediate set of questions: whether liberalising trade results in increased trade and why; and if so, whether any increase is symmetrical/mutually advantageous as represented by equal gains in exports, imports and overall balance of trade; whether we witness trade creation or simply trade diversion; and finally, what the relationship between increased trade and increased productivity is. The current study does not seek to assess the impact of the JUSFTA on overall Jordanian economic growth and welfare and in effect precedes Rodriquez and Rodrik's discussion by first identifying if there is a correlation between the implementation of the JUSFTA and changes Jordanian-US trade levels (further study of the impact on Jordanian economic development would then be possible in further studies).

A more nuanced approach to estimating the impact of FTAs on changes in bilateral trade levels is the Gravity Model, and variations of it, which considers several variables, including the form of a given FTA (reciprocal/bilateral, and nonreciprocal/unilateral); preFTA bilateral trade flows; pre-FTA GDP; geographical distance and adjacency between signatories; and language similarities/differences (Cipollina and Salvatici, 2010 , p. 64). Gravity models are used to produce projections of future bilateral trade levels (imports, exports and balances of trade) using pre-FTA data and common variables that are not likely to change (such as language and geography) and, according to Cipollina and Salvatici (2010) empirical results of these models can vary quite significantly between studies of the same case. This represents a concern with using a Gravity Model approach in some cases. Nevertheless, Gravity Models are considered by many researchers the most reliable and through method to project future trade levels under FTAs. As this study seeks to examine existing data on pre-JUSFTA and post-JUSFTA bilateral trade to comment on any correlation between the FTA and the actual experience of bilateral trade between Jordan and the United States, and does not aim to present projections of future trade levels, use of a Gravity Model approach is not useful.

\section{METHODOLOGY}

This study uses a quantitative approach to collect, analyse 
Table 2. Jordanian trade with the United States in US\$ Millions (1992-2012).

\begin{tabular}{cccc}
\hline Year & Imports & Exports & Balance \\
\hline 2012 & 1711.6 & 1155.5 & -556.1 \\
2011 & 1484.23 & 1082.77 & -401.46 \\
2010 & 1233.63 & 1023.4 & -210.23 \\
2009 & 1272.15 & 986.4 & -285.75 \\
2008 & 999.68 & 1209.33 & 209.65 \\
2007 & 944.86 & 1466.51 & 521.65 \\
2006 & 737.73 & 1613.3 & 875.57 \\
2005 & 749.08 & 1473.05 & 723.97 \\
2004 & 663.09 & 1314.64 & 651.55 \\
2003 & 611.57 & 836.5 & 224.93 \\
2002 & 511.82 & 521.94 & 10.12 \\
2001 & 439.34 & 297.04 & -142.3 \\
2000 & 417.27 & 96.52 & -320.75 \\
1999 & 375.37 & 41.8 & -333.57 \\
1998 & 493.59 & 22.93 & -470.66 \\
1997 & 571.8 & 35.94 & -535.86 \\
1996 & 498.74 & 36.41 & -462.33 \\
1995 & 498.97 & 43.01 & -455.96 \\
1994 & 438.07 & 44.39 & -393.68 \\
1993 & 564.34 & 29.42 & -534.92 \\
1992 & 415.4 & 29.18 & -386.22 \\
Totals & $\mathbf{1 5 6 3 2 . 3 3}$ & $\mathbf{1 3 3 5 9 . 9 8}$ & $-\mathbf{2 2 7 2 . 3 5}$ \\
\hline
\end{tabular}

and present data. The nature of the relationship being examined here - bilateral trade relations between Jordan and the United States - requires the collection of empirical data on annual levels of imports and exports, and the subsequent calculation of annual and full period trade balances. The US Department of Commerce's Census Bureau database on foreign trade was used to collect data on Jordanian-US bilateral trade (imports, exports and trade balance) in constant US\$. Corroboration of the data was achieved by using the Jordanian Ministry of Trade and Industry's 'Trade and Investment Information System' (TIIS) database, which was used to collect the same data for the same period of time in constant Jordanian Dinars and converted to constant US\$. In order to understand the nature of bilateral trade and the impact that the JUSFTA has had, it was necessary to identify a period of time to be investigated that offers sufficient comparative data before and after the JUSFTA was implemented. The agreement came into force in late December 2000 and the available data covers bilateral trade through to the end of 2012 offering 12 years of JUSFTA-era data. In order to offer a comparative range of data from the pre-FTA era from 1992 onwards was collected. It must be noted that 1992 is the earliest year that data on bilateral trade between Jordan and the United States is available, and while this limits the extent to which concrete conclusions can be drawn, in the absence of earlier data there is no alternative approach available. This data provides a full range of 21 years of bilateral data including nine years of pre-JUSFTA data. The agreement itself acts as an independent variable in this analysis.

In order to examine this relationship levels of imports and exports were differentiated as this is necessary in order to understand the nature of the trade taking place. By only looking at total trade levels we would be able to conclude whether trade has increased, decreased or remained relatively constant post-JUSFTA, which is itself an important observation. But we would not be able to understand whether there was a balance or imbalance in trade, and in which state's favour. This latter point is very important when considering economic growth and development in small markets like Jordan. With this in mind data on the balance of trade between the two states over the 21 year period was also collected and analysed. The data collected was processed and collated as shown in Table 2. In order to analyse the data a series of graphs to represent the actual, projected and comparative data were produced and can be found below in the results section. Actual levels of Jordanian imports, exports and trade balance by year for the whole period are presented in Figure 1. Analysis was conducted on the data for the pre-JUSFTA period to produce linear trendline projections (Figure 2) to offer a projection of what the annual levels of bilateral trade could have been expected to be which is then compared with the post-JUSFTA experiences of trade. This allows us to compare the projections of trade from 2001 to 2012 with the actual data for that period and determine the level of difference. Here, higher levels of actual trade compared to the projections in the JUSFTA period would suggest that the agreement has facilitated trade, while constant or lower levels of actual trade compared to projected trade would suggest it has not.

The data has also been processed to produce a summary of imports, exports and balance of trade for the pre- and post-JUSFTA periods in order to determine if either state has benefitted more than the other (Figure 3). It was useful to examine linear trendline averages for 2001 to 2012 based on pre-JUSFTA data in order to understand the likely future development of this bilateral trade relationship and Figure 4 was produced for this purpose.

\section{RESULTS AND DISCUSSION}

Analysis of the data reveals several key facts regarding the nature of change in Jordanian-US trade and the impact of the JUSFTA. Let us deal with the pre-JUSFTA period first. Between 1992 and 2000 bilateral trade between Jordan and the United States remained largely constant with little variation over the nine-year period. In constant US $\$$ prices the highest level of imports was $\$ 571.8$ million in 1997 while the lowest level of imports was $\$ 375.37$ million in 1999 (a variation of only $\$ 196.43$ million). Jordanian exports to the United States varied even less with the highest value of exports being 


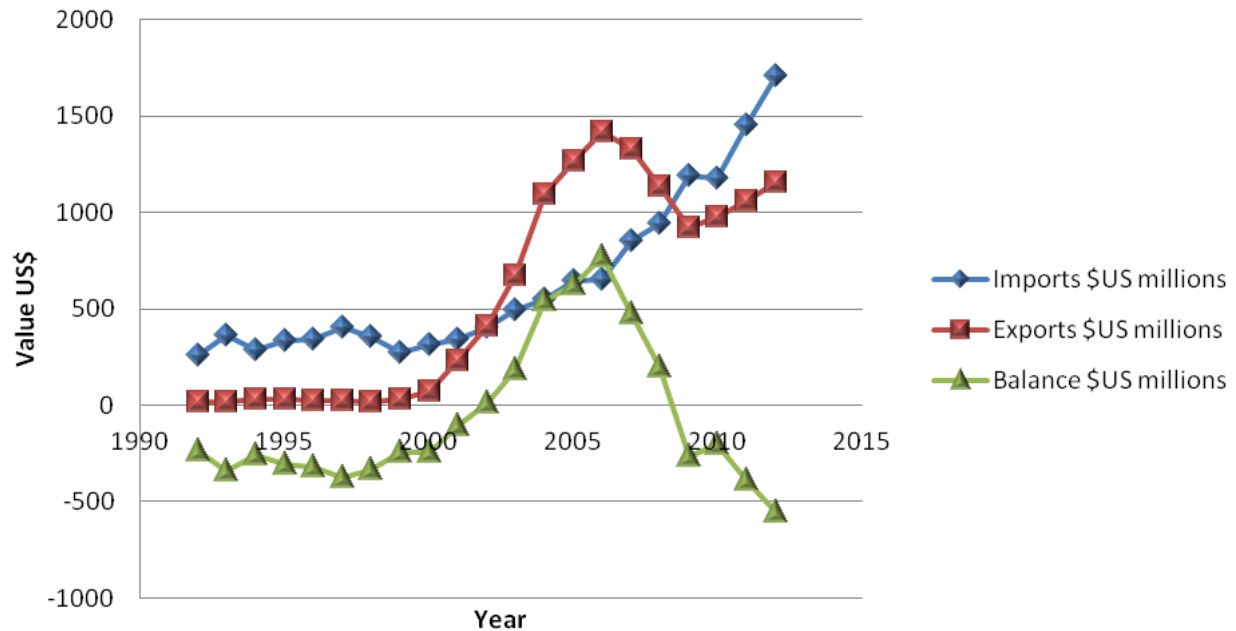

Figure 1. Jordanian trade with the USA: 1992-2012.

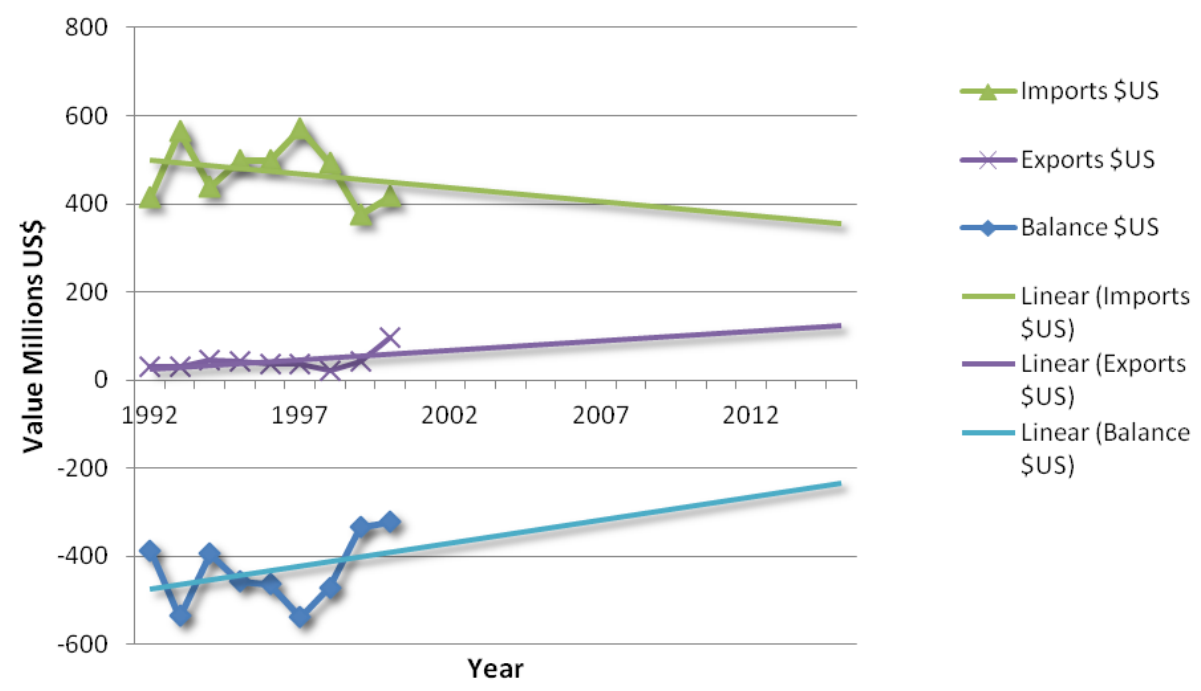

Figure 2. Jordanian trade with the USA: 1992-2000 and projections: 2001-2012.

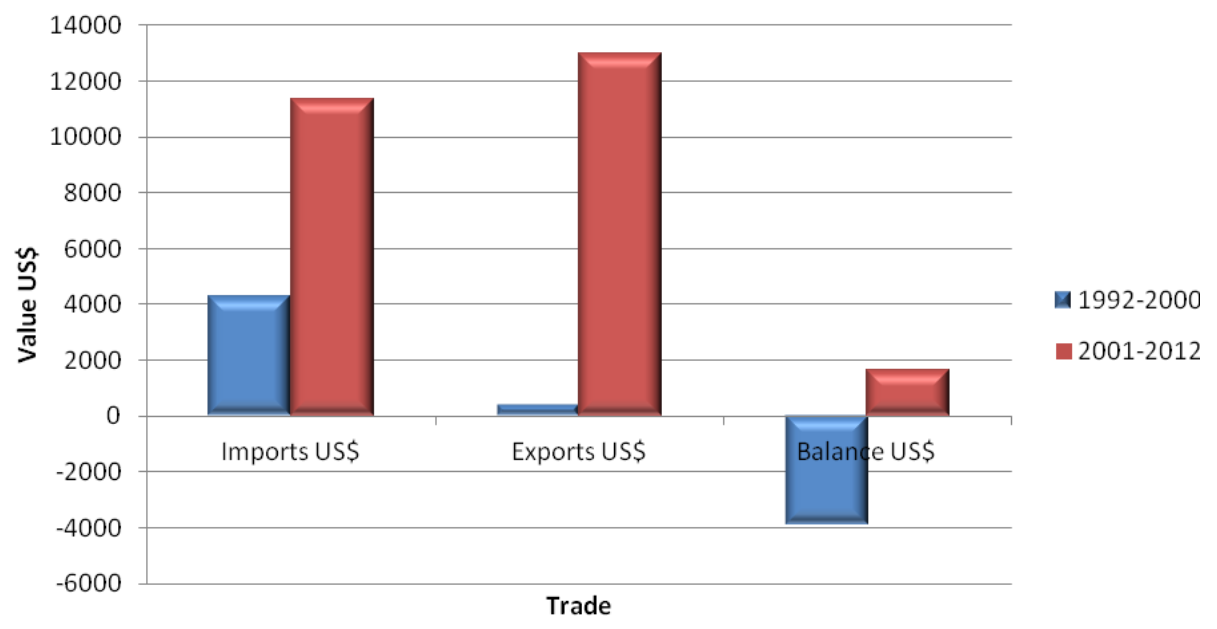

Figure 3. Jordanian trade with the USA pre-FTA and post-FTA comparison. 


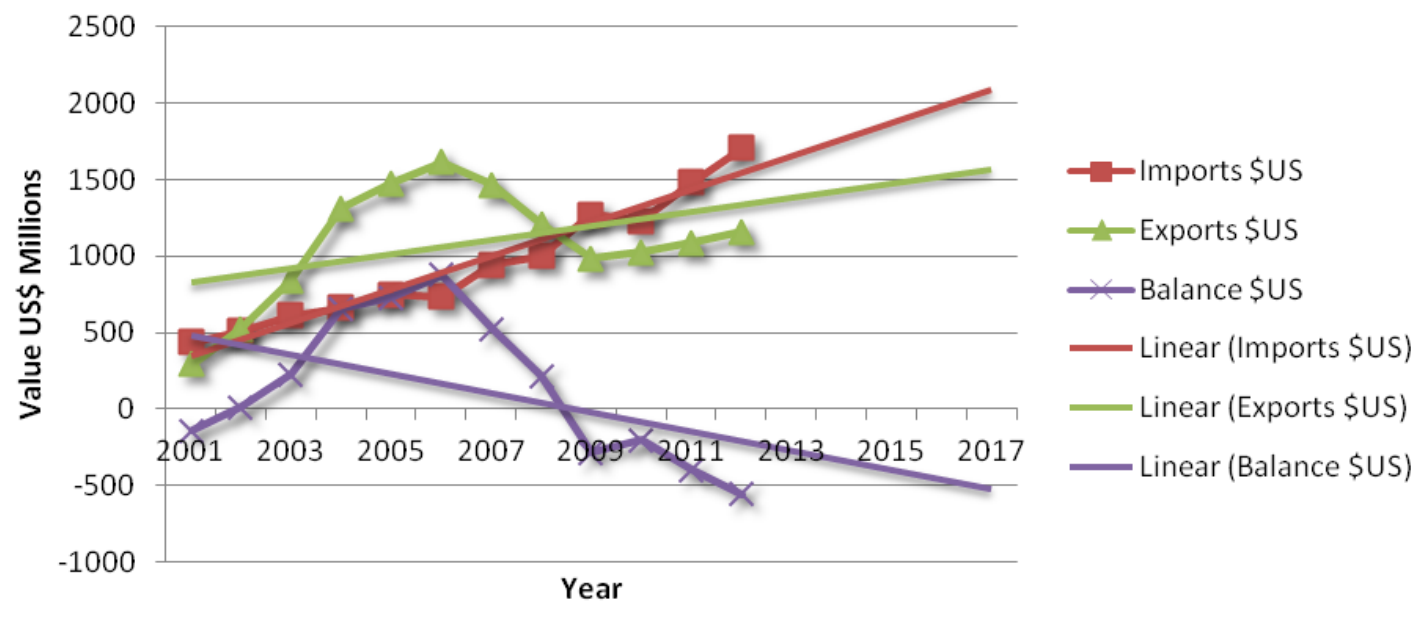

Figure 4. Jordanian trade with the USA: 2001-2012 - Linear trendline average.

witnessed in 2000 totalling $\$ 96.52$ million, while 1998 saw the lowest value at just $\$ 22.93$ million (a variation of $\$ 73.59$ million). Perhaps the most important observation we can make from this period is that Jordan was constantly experiencing a trade deficit with the United States ranging from a minimum of $\$ 320.75$ million in 2000 to a maximum of $\$ 535.86$ million in 1997 . Overall, during the nine years prior to the implementation of the JUSFTA approximately $\$ 3893.95$ billion flowed out of the Jordanian economy and into the US market. Trade with the United States was low compared to Jordan's key trading partners during this period suggesting that this bilateral trade relationship was underdeveloped.

The nature of trade between Jordan and the United States looks very different for the post-JUSFTA period (2001 to 2012). When Figures 1, 2 and 3 are compared the impact of the JUSFTA is extremely clear. The linear trendline projections for imports, exports and the balance of trade in the absence of the JUSFTA identify Jordanian exports as growing only slightly to just over $\$ 100$ million by 2012 , while imports would remain in the range of $\$ 400$ million. The overall balance of trade would remain in favour of the United States. However, with the JUSFTA in effect since December 17 2000, immediately, significant changes can be observed. In 2001, the first year of the JUSFTA (not counting the two weeks or so at the end of 2000) there was an increase in overall trade, notably with an increase in Jordanian exports to the US market totalling just over $\$ 297$ million (up from $\$ 96.52$ million the year before). This trend continued through to 2006 when Jordanian exports peaked at $\$ 1.613$ billion. This means that in just six years Jordanian exports to the United States increased by more than $1900 \%$. Imports from the United States also increased in this period, although somewhat more slowly than exports, growing constantly in each year since 2001 and reaching $\$ 1.233$ billion by 2010. During 2011 and 2012 a rather rapid increase in imports was witnessed with Jordan importing $\$ 1.7116$ billion of goods and services from the United States in the latter year. Jordanian exports on the other hand declined for three years in a row from 2007 (\$1.466 billion) to 2009 (\$986 million) before again increasing year on year and climbing back up to $\$ 1.1555$ billion in 2012 . It is likely that the financial crisis of August 2008 and the subsequent recession in the United States dampened US demand for Jordanian goods through the 2008-2010 period and the sluggish growth in the US market in 2011 and 2012 also have repressed US imports overall.

The decline observed between 2007 and the first half of 2008 is more unexpected. Given the nature of Jordanian exports to the United States (discussed below) it is likely that this is linked to the end of the Multi-Fibre Arrangement (MFA) (Pigato and Diop, 2006). This WTOnegotiated global agreement placed barriers to trade in textiles and apparel between large developing markets and others (primarily the advanced markets of the global north). It protected the US market from an influx of textiles and apparel produced in major developing markets (especially China and India) that did not have FTAs with the United States. At the same time the MFA protected the exports of states like Jordan that had preferential access to the US market from competition. A previous investigation into Jordanian-US trade concluded that the majority of Jordanian exports up until the end of the MFA on January 12005 were textiles and apparel products (El-Anis, 2011, pp. 135-169) meaning that when the MFA ended Jordan's exports to the United States were directly open to increased competition and subsequently received a smaller share of the US market.

Nevertheless, even given the steady increase in imports from the United States and slight decline in exports, Jordan experienced an overall trade surplus of over $\$ 1.621$ billion in this period. The largest bilateral trade surplus was witnessed in 2006 and totalled $\$ 875.57$ million. Furthermore, Jordan had a surplus each year from 2002 until 2009, which saw a return to an overall 
Table 3. Jordanian trade with GAFTA in US $\$$ millions (19932008).

\begin{tabular}{ccccc}
\hline Year & Imports & Exports & Total & Balance \\
\hline $\mathbf{1 9 9 3}$ & 719.76 & 411.2 & 1130.96 & -308.56 \\
$\mathbf{1 9 9 4}$ & 749.11 & 482.2 & 1231.31 & -266.91 \\
$\mathbf{1 9 9 5}$ & 854.1 & 642.13 & 1496.23 & -211.97 \\
$\mathbf{1 9 9 6}$ & 1039.2 & 674.3 & 1713.5 & -364.9 \\
$\mathbf{1 9 9 7}$ & 931.12 & 764.4 & 1695.52 & -166.72 \\
$\mathbf{1 9 9 8}$ & 788.8 & 634.4 & 1350.8 & -82 \\
$\mathbf{1 9 9 9}$ & 1077.25 & 570.9 & 1359.7 & -217.9 \\
$\mathbf{2 0 0 0}$ & 1092.9 & 608.6 & 1701.5 & -484.3 \\
$\mathbf{2 0 0 1}$ & 1162.1 & 961.6 & 2123.7 & -200.5 \\
$\mathbf{2 0 0 2}$ & 1282.7 & 1046.3 & 2329 & -236.4 \\
$\mathbf{2 0 0 3}$ & 1584.3 & 977.1 & 2561.4 & -607.2 \\
$\mathbf{2 0 0 4}$ & 2506.4 & 1335.8 & 3842.2 & -1170.6 \\
$\mathbf{2 0 0 5}$ & 3552.7 & 1547.6 & 5100.3 & -2005.1 \\
$\mathbf{2 0 0 6}$ & 4137.2 & 1763.6 & 5900.8 & -2373.6 \\
$\mathbf{2 0 0 7}$ & 4532.6 & 1967 & 6499.6 & -2565.6 \\
$\mathbf{2 0 0 8}$ & 5639.7 & 2567.1 & 8206.8 & -3072.6 \\
\hline
\end{tabular}

deficit with the United States gaining a $\$ 285.75$ million surplus. Worryingly, from the Jordanian perspective, this trade deficit has continued to grow and totalled $\$ 556.1$ million in 2012. A return to an overall trade deficit in this bilateral relationship is possible over the next decade. However, analysis of the linear trendline projections suggests that over the period of study, Jordanian exports to the United States have performed better that may have been expected and the projection for the next few years suggests that a return to a Jordanian trade surplus is possible. This is reinforced by the net effect of the JUSFTA on Jordanian exports (increased by over $\$ 12.6$ billion) compared to the net effect on imports (increased by just over $\$ 7$ billion) as demonstrated by Figure 3 .

To provide some context to the importance of the changes in bilateral trade between Jordan and the United States it is useful to compare patterns of trade between Jordan and Greater Arab Free Trade Area (GAFTA) members, and with European Union members through an Association Agreement (JEUAA). The GAFTA agreement was signed in 1997 and came into full force on January 1 2005. It covers 18 member states of the Arab League (Algeria, Bahrain, Egypt, Iraq, Jordan, Kuwait, Lebanon, Libya, Mauritania, Morocco, Oman, Qatar, Saudi Arabia, Syria, Tunisia, UAE) and stipulates the complete liberalisation of trade in goods (but not in services which are still protected to an extent). The tariff and other barrier reduction schedule in the agreement is characterised by a planned $10 \%$ reduction per year starting in 1997 and ending in a target of $0 \%$ by 2010 (Hoekman and Zarrouk, 2003). Table 3 summarises total Jordanian trade with GAFTA members from 1993 to 2008. Three key observations can be made: firstly, that Jordan's total trade, imports and exports with this trade block increased in this period of time; secondly, there is no clear point of change in the rate of increase following the scheduled reduction in barriers; finally, the total increase in trade levels is not as significant as was witnessed between Jordan and the United States postJUSFTA. Similarly, the Association Agreement that Jordan signed with the European Union in 1997 and which was ratified in 2002 calls for the reduction of tariffs and other barriers to trade in goods and services over a ten year period. Yet trade between the two parties remains limited with Jordanian exports to the EU remaining almost constant at around \$200-400 million annually since the mid-1990s (Eurostat, 2013).

\section{CONCLUSIONS}

This study has considered the available primary data on bilateral trade between Jordan and the United States between 1992 and 2012 and has considered the correlation between changes over this period of time and the implementation of the JUSFTA. While there are limitations to how far this investigation can go (namely the limited range of years for which reliable data is available (only from 1992 onwards) and difficulty with offering projections for future trade based on only nine years of data (1992-2000) and linear trendlines) a number of key observations can be made. The implementation of the JUSFTA coincides with an increase in overall bilateral trade between Jordan and the United States strongly suggesting a positive effect of institutionalised trade facilitation in this case. However, as noted above, FTAs do not necessarily result in increased trade levels. What they do is create the regulatory framework (through deregulation) to encourage trade to take place by lowering barriers to trade. The actual realisation of increased trade results not from governmental policy but from the agency of the actors that are directly engaged in the production, transportation and consumption of goods and services. In the Jordanian-US case, therefore, we can posit that the JUSFTA has allowed for complimentary market forces to develop and for trade in goods between the two markets to grow. Without the JUSFTA in place it is likely that trade would not have grown as significantly or as rapidly. The overall impact on economic growth and development in Jordan, however, is not so clear. Of importance here is that any assessment of the differences between projections of bilateral trade in the absence of the JUSFTA are based on only nine years of available (reliable) pre-JUSFTA data. This places limitations on the ability to project bilateral levels of trade with a low margin of error.

We can observe that exports to the United States have grown to very high levels compared to those experienced pre-JUSFTA and this has certainly resulted in greater economic activity in Jordan. Money has been earned by selling to the US market; jobs have been created in 
Jordan; capital and technology have been attracted to Jordan (Kardoosh, 2006). But at the same time, the overall trend since 2007 has meant that Jordan now finds itself once again experiencing a trade deficit with the United States (indeed larger than ever before) meaning that a net flow of wealth is going to the latter. This may be due to the variation in the impact of the 2008 financial crisis on Jordan (which was not significantly impacted due to its lower exposure to financial markets) and the United States (which was heavily exposed) and the subsequent decline in US imports and steady growth of the Jordanian economy. Alternatively, this could demonstrate the steady exploitation of the Jordanian market by US-based actors who are able to compete more effectively. In this scenario, the JUSFTA facilitated equal market access but the US-based actors exploiting this access are more capable than their Jordanian-based counterparts. In other words, the JUSFTA has created the fabled level playing field advocated by neoclassical economists, but the players belong to different leagues. As the United States continues to recover from the effects of the 2008 financial crisis we should see its overall imports increase in the coming years. It will be interesting to see if Jordanian exports to the United States continue to grow also. It will also prove useful to consider the variations in Jordanian trade patterns with other FTA signatories, including blocks like GAFTA and the EU as they unfold in the coming years and compare them to Jordanian-US trade patterns as more data becomes available.

\section{REFERENCES}

Andre GF (1978). Dependent Accumulation and Underdevelopment. New York, Monthly Review Press.

Anon (2000). Agreement Between The United States of America and The Hashemite Kingdom of Jordan on the Establishment of a Free Trade Area. http://www.mit.gov.jo/Portals/0/TextOA/AGREEMENT_TEXT.pdf

Baksi S, Chaudhuri AM (2009). On Trade Liberalization and Transboundary Pollution. Econ. Bull. 29:2605-2612.

Baksi S, Chaudhuri AR (2008). Transboundary Pollution, Trade Liberalisation and Environmental Taxes in Tilburg Law and Economics Center Discussion Paper. No. 2008-033:1-23.

Cassing J, Salameh AM (2006). Jordan-United States Free Trade Agreement Economic Impact Study: Searching for Effects of the FTA on Exports, Imports and Trade Related Investments. Amman, USAID Jordan.

Cipollina M, Salvatici L (2010). Reciprocal Trade Agreements in Gravity Models: A Meta-Analysis. Rev. Int. Econ. 18(1):63-80.

El-Anis I (2011). Jordan and the United States: the political economy of trade and economic reform in the Middle East. London, I.B. Tauris.

El-Said H (2001). Waiting for Privatisation in the Arab World: the Case of Jordan in El-Said, $\mathrm{H}$ and Becker, $\mathrm{K}$. Management and International Business Issues in Jordan. Binghampton, International Business Press.

Eurostat Data (2013). http://epp.eurostat.ec.europa.eu/portal/page/ Foreign\%20Trade\%20Policy.aspx.

Frankel J, Rommer D (1999). Does Trade Cause Growth? Am. Econ. Rev. 89(3):379-399.

Hamarneh M (1994). The Jordanian Economy: Problems and Prospects. Amman, Centre for Strategic Studies.
Harrison A (1996). Openness and Growth: A Time-Series, CrossCountry Analysis for Developing Countries. J. Dev. Econ. 48(2):419447.

Hoekman B, Zarrouk J (2003). Catching Up With the Competition: Trade Opportunities and Challenges for Arab Countries, Ann Arbor, The University of Michigan Press.

Jagdish B (2003). Free Trade Today. Princeton, Princeton University Press.

Jardaneh D (2003). US-Jordan Free Trade Agreement: Reaching the Finish Line. Amman, Atlas Investment Group.

Jordanian Ministry of Industry and Trade (2013). Jordan's Foreign Trade Policy. http://www.mit.gov.jo/tabid/475/Jordan\%20

Jordanian Ministry of Industry and Trade (2013). Trade and Investment Information System. http://questionare.dos.gov.jo/tiis/(S(bbew2apt21

Kardoosh M (2006). The Institutional Dimension of the Success of Jordanian QIZs. Amman, Jordan Centre for Public Policy Research and Dialogue.

Lawrence R (2006). A US-Middle East Trade Agreement: A circle of opportunity? Washington, DC, Peterson Institute.

Lovett, WA, Brinkman, RL, Eckes, AE, Eckes, AE Jr (2005). US Trade Policy: History, Theory and the WTO. Washington, DC, Peterson Institute.

Maciejewski E, Mansur A (1996). Jordan: Strategy for Adjustment and Growth. IMF Occasional Paper No. 136.

Ministry of Industry and Trade (2006). Implementation of the JUSFTA: Review. Amman, Ministry of Industry and Trade.

Nkuiya B (2013). Trade Structure, Transboundary Pollution and Multilateral Trade Liberalization: The Effects on Environmental Taxes and Welfare. Environ. Resour. Econ. 55:337-355. obiwhdfvhihux1))/HomePage e.aspx.

Pigato M, Diop N (2006). Morocco, Tunisia, Egypt and Jordan After the End of the Multi-Fibre Agreement: Impact, Challenges and Prospects. Washington, DC, World Bank. portal/international trade/introduction.

Ricardo D (1996 [1817]). Principles of Political Economy and Taxation. New York, Prometheus Books.

Robins P (2004). A History of Jordan. Cambridge, Cambridge University Press.

Rodriguez F, Rodrik D (2001). Trade Policy and Economic Growth: A Skeptic's Guide to the Cross-National Evidence in NBER Macroeconomics Annual 2000, Natl. Bur. Econ. Res. 15:261-338.

Rosen H (2003). Free Trade Agreements as US Foreign Policy Tools: The US-Israel and US-Jordan FTAs in Schott, JJ (ed.) Free Trade Agreements: US Strategies and Priorities. Washington, DC, Peterson Institute for International Economics.

Sachs J, Warner A (1995). Economic Reform and the Process of Global Integration. Washington, DC, Brookings Institute.

Salibi K (1998). The Modern History of Jordan, London, I.B. Tauris.

Sebastian E (1993). Openness, Trade Liberalization, and Growth in Developing Countries. J. Econ. Lit. 31(3):1358-1393.

Smith A (2003 [1776]). The Wealth of Nations. New York, Bantam Classics.

Tovias A, Al-Khouri R (2004). An Empirical Estimation of the Potential Economic Effects of a Bilateral Free Trade Area Agreement Between Israel and Jordan in the Context of the Euro-Mediterranean Partnership. Israel Aff. 10(3):138-158.

US Census Bureau (2013). Foreign Trade Statistics. http://www.census.gov/foreign-trade/balance/index.html.

USTR (2005). The US-Jordan FTA Fact Sheet. Washington, DC, Office of the United States Trade Representative.

Wallerstein I (1979). The Capitalist World Economy: essays. Cambridge, Cambridge University Press.

Williamson J (1990). Latin American Adjustment: How much has happened? Washington, DC, Peterson Institute.

World Bank (2012). Jordan Country Report. Washington, DC, World Bank. http://data.worldbank.org/country/jordan\#cp_wdi.

World Trade Organisation (2008). Trade Policy Review - Jordan. Geneva, World Trade Organisation. http://www.mit.gov.jo/portals/0/g206.pdf. 